\title{
UMOD geneassociated renal failure patients have unusual minerals and nitrogenous wastes levels after hemodialysis
}

\begin{abstract}
Background: Mutations in the Uromodulin gene lead to end-stage renal disease and subsequent complications; therefore, the aim of this study was to assess the influence of Uromodulin gene mutation on possible minerals and nitrogenous wastes levels after hemodialysis.
\end{abstract}

Design and methods: One hundred patients with renal failure and under hemodialysis were investigated. Genetic analysis of Uromodulin gene mutation, as well as, minerals and nitrogenous waste were analyzed.

Results: Of the 100 patients, 9 were detected with Uromodulin gene mutation. Exons 4 and 5 , in which $95 \%$ of all $U M O D$ mutations were found in 5 patients of whom, $3(60 \%)$ were males and $2(40 \%)$ were females (all mutations were previously described).

Conclusion: Patients with renal failure have more potentiality for deteriorated Minerals and nitrogenous wastes than others

Keywords: CKD, Saudi Arabia; renal failure, uromodulin gene, minerals, hemodialysis, nitrogenous wastes
Volume 4 Issue 2 - 2017

\author{
Hussain Gadelkarim Ahmed, Bassam Ahmed \\ Almutlaq, Rakan Fraih Almuazzi, Fahad \\ Awadh A Alnamassi, Abdullah Abdulaziz A \\ Almulifi, Njoud Meshoweh Alenezi, Khalid \\ Oqalaa Alshammari, Bandar Saleh Alamro \\ College of Medicine, University of Hail, Saudi Arabia
}

Correspondence: Hussain Gadelkarim Ahmed, College of Medicine, University of Hail 2240, Hai'l, Saudi Arabia,Tel 966502609300,Email hussaingad1972@yahoo.com

Received: January 01, 2017 | Published: February 21, 2017
Abbreviations: CKD, chronic kidney disease; ESKD, end stage kidney disease; ESRD, end-stage renal disease; CRF, chronic renal failure; CKF, chronic kidney failure; KSA, kingdom of Saudi Arabia; GFR, glomerular filtration rate; UMOD, uromodulin; PCR, polymerase chain reaction; mg, milligrams; $\mathrm{dL}$, deciliter; UAKDs, uromodulin associated kidney diseases; $\mathrm{SCr}$, serum creatinine concentration; TAL, thick ascending limb; ADTKD, a dominant form of tubulointerstitial kidney disease; AVF, arteriovenous fistula

\section{Introduction}

Chronic kidney disease (CKD), is progressive loss in kidney function over a period of time may be month or years. The symptoms of kidney function deterioration are not specific, until advanced stages are reached. In most instances, CKD is diagnosed as a result of screening of people known to be at risk of kidney disorders, such as those with high blood pressure or diabetes and those with relative with CKD. ${ }^{1,2}$ Stage 5 CKD is known as end-stage kidney disease (ESKD), end-stage renal disease (ESRD), or end-stage kidney failure (ESKF), and is largely synonymous with the now outdated terms chronic renal failure (CRF) or chronic kidney failure (CKF). All these terms mean that the patient requires Kidney replacement therapy, which may consist of a form of hemodialysis, but preferably constitutes a renal transplant. Up-to-date international guidelines reclassified CKD based on cause, glomerular filtration rate (GFR) category (G1, G2, G3a, G3b, G4 and G5), and albuminuria category (A1, A2, A3). ${ }^{3}$

The prevalence and incidence of ESRD is increasing in Saudi Arabia in recent years. This increase exceeds those reported from diverse countries. ${ }^{4}$ The huge and rapid changes in lifestyle, vast population growth, and fast rise in life expectancy, and substantial urbanization that has happened recent years shared to make the current CKD status different to what was expected. ${ }^{5}$ The common major risk factors that influence the CKD status are the increasing prevalence of mellitus (DM), ${ }^{6}$ hypertension, ${ }^{7}$ obesity ${ }^{8}$ and shift in age demographics. ${ }^{5}$ Uromodulin (UMOD) -associated kidney disease is one of a group of autosomal dominant interstitial kidney diseases which is caused by mutations in the UMOD gene. Patients with UMOD-associated kidney disease present with hyperuricemia, gout, and progressive kidney failure. The disease is believed to be uncommon but is perhaps under diagnosed. ${ }^{9}$ Uromodulin gene encoding uromodulin, the most abundant urinary protein. ${ }^{10}$ Most individuals diagnosed with $U M O D$ related kidney disease have an affected parent. Each child of an affected individual has a $50 \%$ chance of inheriting the pathogenic variant. ${ }^{11}$ However, it was proposed that disturbances of minerals and nitrogenous waste may predict Uromodulin gene mutation. Therefore, the aim of the present study was to assess the influence of Uromodulin gene mutation on Minerals and Nitrogenous wastes levels in Hemodialysis Patients.

\section{Materials and methods}

This study was conducted in Renal Failure Unit at King Khalid Hospital, Hail, Kingdom of Saudi Arabia (KSA), during the period from 1st of January to 30 of December 2015. One hundred patients with renal failure (under hemodialysis) were selected by systemic random method. All patients were previously diagnosed as having renal failure and currently were under hemodialysis. All data in the present study were taken from patients' records. All records regarding patients with renal failure were retrieved from renal failure unit. Data 
regarding the demographical characteristics, as well as, nitrogenous wastes and minerals were obtained from patients' files. Peripheral Blood samples were taken as a part of the specimen required for routine examination. Blood samples were further tested for possible Uromodulin Gene Mutation by Polymerase Chain Reaction (PCR). Normal levels of serum creatinine in the blood are 0.6 to 1.3 milligrams (mg) per deciliter (dL) in adult males and 0.5 to 1.2 milligrams per deciliter in adult females. More than these levels were considered as high, and lower than these levels were considered as low. Urea levels of 7 to $30 \mathrm{mg} / \mathrm{dL}$ ( 2.5 to $7.1 \mathrm{mmol} / \mathrm{L}$ ) is considered normal. More than these levels were considered as high, and lower than these levels were considered as low.

\section{UMOD gene's mutation analysis}

Genomic DNA was isolated from blood samples following the manufacturer's kits' instructions (Beijing Aidlab Biotechnology Co., Ltd.). We analyzed UMOD gene's exons 4 and 5 by exon PCR and direct sequencing of the UMOD gene. The Primer sequences were performed adopting the method defined elsewhere, ${ }^{12}$ employing primers described in Table 1. The products of PCR were purified, sequenced and analyzed using the CEL I assay. The CEL I assay was shown to be extremely sensitive for mutational analysis, simple, effective and inexpensive, as described by Wolf et al. ${ }^{13}$ For endonuclease preparation by CEL I assay; Exons 3 and 6-12 were tested by exon PCR, CEL I endonuclease digest and heteroduplex analysis with sequential sequencing of products producing atypical bands. Preparation of crude extract comprising $30 \mathrm{kDa}$ single strand specific endonuclease CEL I was purified from celery as defined elsewhere. ${ }^{14}$

Since exons 1 and 2 do not encode translated parts of UMOD gene, they have only $5^{\prime}$ untranslated regions and were thus not contained within in the analysis. The CEL I endonuclease enzyme identifies single base discrepancies existing in heteroduplex DNA and cleaves both strands. Heteroduplex DNA was gained by heat-denaturing $2 \mu \mathrm{l}$ of an exon-PCR amplified patient's DNA sample. DNA fragments were denatured at $95^{\circ} \mathrm{C}$ for 10 minutes followed by slow cooling. The reaction component was incubated at $45^{\circ} \mathrm{C}$ for 5 minutes, placed on ice, and stopped by mixing with glycerol-containing (30\%) loading buffer accompanied with EDTA (final concentration $250 \mathrm{mM}$ ) followed by a $1.5 \%$ agarose gel electrophoretic separation of the digested fragments for 1 hour at $150 \mathrm{~V}$. Samples displaying atypical bands were purified and directly sequenced.

Table I Primer sets for exon 4-5 amplification of the UMOD gene (Primer $\left(5^{\prime} \rightarrow 3^{\prime}\right)$ ).

\begin{tabular}{llll} 
Exon & Forward & Reverse & Size (bp) \\
5-Apr & GGTGGAGGCTTGACATCATCAGAG & GGAATAGGGCTCAGATGGTCTTTG & 1493 \\
& GCCCTGGCCTCATGTGTCAATGTG & GGGTCACAGGGACAGACAGACAAT & \\
& CGGCGGCTACTACGTCTACAACCT & GTAGCTGCCCACCACATTGACACA & \\
\hline
\end{tabular}

\section{Statistical analysis}

For all statistical analyses, the SPSS statistical software version 16 was used. Pearson chi square test was used and P. values of 0.05 or less were regarded as statistically significant.

\section{Results}

In the present study the genomic DNA of 100 patients with renal failure from different families living in North Saudi were analyzed. The mean age at analysis was 52 years (range 10 to 99 years), of the 100 patients 65 were males and 35 were females, giving males' females' ration of 1.86:1.00. The estimated mean GFR at investigation was $40.3 \mathrm{ml} / \mathrm{min} / 1.73 \mathrm{~m} 2$ (range 12 to $76.4 \mathrm{ml} / \mathrm{min} / 1.73 \mathrm{~m} 2$ ). Exons 4 and 5, in which $95 \%$ of all $U M O D$ mutations were found in 5 patients of whom, $3(60 \%)$ were males and $2(40 \%)$ were females (all mutations were previously described). In regard to the age, most positive cases were among elderly population (over 50 years old), as indicated in Table 2. This gradual increased with age was found when we calculated the positivity proportions with the positive cases, as shown in Figure 1. In regard to the nitrogenous wastes, high creatinine levels were demonstrated among all cases with Uromodulin gene mutation $(100 \%)$, since high urea levels were found in $66.7 \%$ of positive cases. Only $11 \%$ of the positive cases were found with high uric acid, as indicated in Table 3, (Figure 2). Table 4 Summarizes the distribution of Uromodulin gene mutation status by Minerals estimates. Low Potassium was identified in $22.2 \%$ of the positive cases, since, low Sodium, low Calcium and Low Chloride levels were identified in $55.6 \%, 100 \%$, and $44.4 \%$, respectively as indicated in Figure 3.

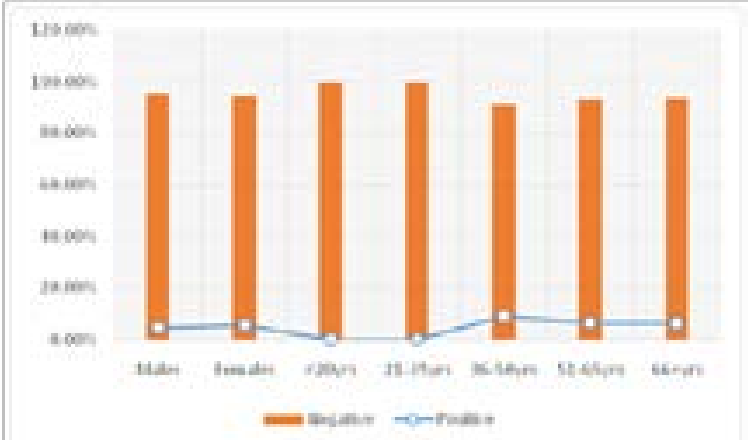

Figure I Description of Positive Uromodulin gene mutation by sex and age.

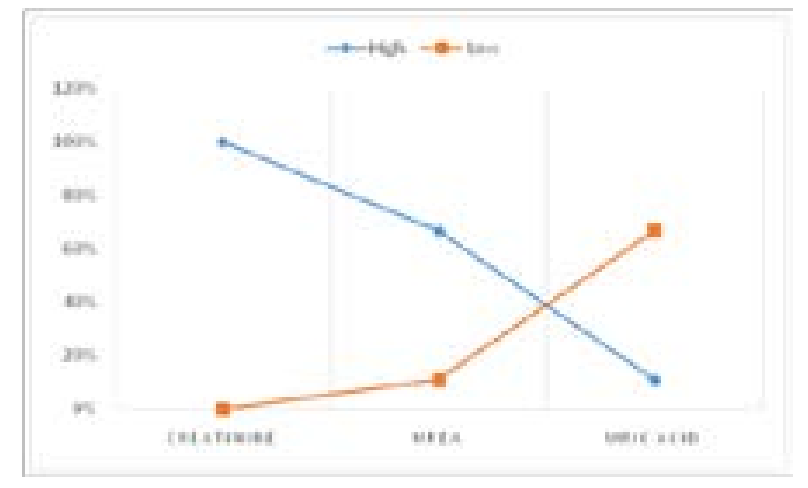

Figure 2 Description of Positive Uromodulin gene mutation by nitrogenous wastes. 


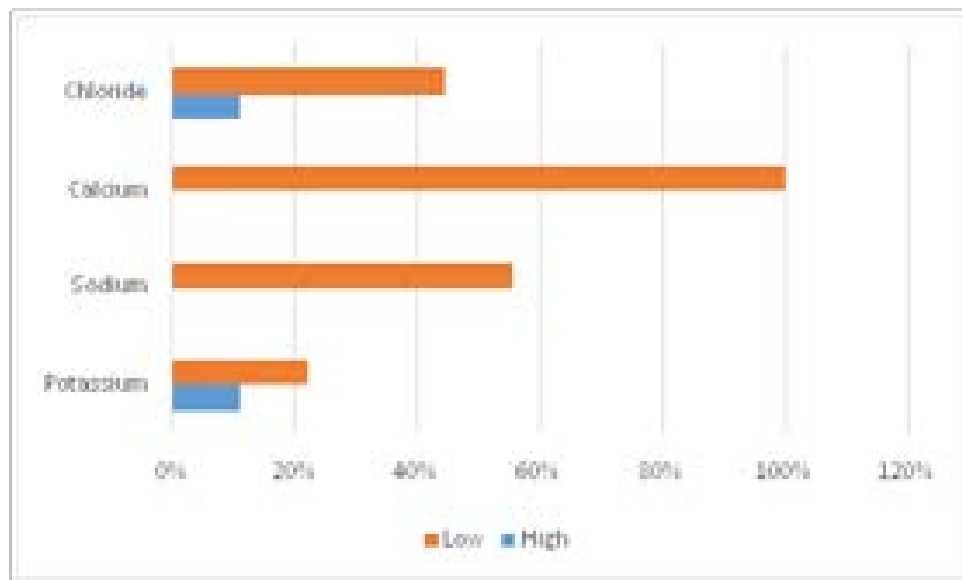

Figure 3 Positive Uromodulin gene mutation by Minerals.

Table 2 Distribution of Uromodulin gene mutation by sex and age

\begin{tabular}{lllllll} 
Variable & Category & \multicolumn{2}{c}{ Uromodulin Gene mutation } & OR (95\% CI) & P Value \\
& \multicolumn{7}{c}{ Positive } & Negative & Total & \\
Sex & Males & 3 & 62 & 65 & $0.65(.16-2.58)$ & 0.54 \\
& Females & 2 & 33 & 35 & & \\
Age & $<20$ years & 0 & 8 & 8 & $0.51(0.027-9.56)$ & \\
& $21-35$ & 0 & 18 & 18 & $1.32(0.25-6.96)$ & 0.74 \\
& $36-50$ & 1 & 10 & 11 & $1.01(0.11-8.95)$ & 0.99 \\
& $51-65$ & 2 & 29 & 31 & $1.10(0.25-4.75)$ & 0.89 \\
& $66+$ & 2 & 30 & 32 & $1.05(0.25-4.50)$ & 0.94
\end{tabular}

Table 3 Distribution of Uromodulin gene mutation by nitrogenous wastes

\begin{tabular}{|c|c|c|c|c|c|c|}
\hline \multirow[t]{2}{*}{ Variable } & \multirow[t]{2}{*}{ Category } & \multicolumn{3}{|c|}{ Uromodulin Gene mutation } & \multirow[t]{2}{*}{ OR (95\% Cl) } & \multirow[t]{2}{*}{ PValue } \\
\hline & & Positive & Negative & Total & & \\
\hline \multirow[t]{3}{*}{ Creatinine } & Low & 0 & I & I & & \\
\hline & Normal & 0 & 6 & 6 & & \\
\hline & High & 5 & 88 & 93 & $1.68(0.08-31.9)$ & 0.72 \\
\hline \multicolumn{7}{|l|}{ Urea } \\
\hline & Low & $\mathrm{I}$ & 7 & 7 & & \\
\hline & Normal & 0 & 32 & 34 & & \\
\hline & High & 4 & 54 & 59 & $1.39(0.32-5.94)$ & 0.65 \\
\hline \multicolumn{7}{|l|}{ Uric Acid } \\
\hline & Low & 4 & 52 & 56 & & \\
\hline & Normal & 0 & 23 & 24 & & \\
\hline & High & 1 & 12 & 12 & $0.90(0.10$ to 7.98$)$ & 0.93 \\
\hline
\end{tabular}

Citation: Ahmed HG,Almutlaq BA,Almuazzi RF, et al. UMOD geneassociated renal failure patients have unusual minerals and nitrogenous wastes levels after hemodialysis. Urol Nephrol Open Access J. 2017;4(2):47-52. DOI: I0.15406/unoaj.2017.04.00I2I 
Table 4 Distribution of Uromodulin gene mutation by Minerals

\begin{tabular}{|c|c|c|c|c|c|c|}
\hline \multirow[t]{2}{*}{ Variable } & \multirow[t]{2}{*}{ Category } & \multicolumn{3}{|c|}{ Uromodulin Gene mutation } & \multirow[t]{2}{*}{ OR (95\% Cl) } & \multirow[t]{2}{*}{$P$ Value } \\
\hline & & Positive & Negative & Total & & \\
\hline \multirow[t]{3}{*}{ Potassium } & Low & 2 & 21 & 21 & $1.06(0.20-5.56)$ & 0.93 \\
\hline & Normal & 2 & 54 & 58 & & \\
\hline & High & 1 & 15 & 16 & & \\
\hline \multicolumn{7}{|l|}{ Sodium } \\
\hline & Low & 4 & 53 & 57 & $0.91(0.23-3.63)$ & \\
\hline & Normal & 1 & 36 & 37 & & \\
\hline & High & 0 & 1 & 1 & & \\
\hline \multicolumn{7}{|l|}{ Calcium } \\
\hline & Low & 5 & 95 & 100 & & \\
\hline & Normal & 0 & 0 & 0 & & \\
\hline & High & 0 & 0 & 0 & & \\
\hline \multicolumn{7}{|l|}{ Chloride } \\
\hline & Low & 3 & 23 & 26 & $2.83(0.70-11.47)$ & 0.14 \\
\hline & Normal & I & 65 & 66 & & \\
\hline & High & I & 7 & 8 & & \\
\hline
\end{tabular}

\section{Discussion}

CKD is a global health problem that is rising for the most part of the world in general and in KSA in particular, as the result of increasing incidences of diabetes, hypertension and other cardiovascular diseases ${ }^{15}$ However, there are many other risk factors contribute to CKD disease and its progression to renal failure. Susceptibility for genetic mutations is a forgotten factor that contributes to development of ESRD and eventual renal failure. Uromodulin is essential protein encoded by $U M O D$ gene and produced in the kidney and contribute to colloid osmotic pressure, retards passage of positively charged electrolytes, prevents urinary tract infection and modulates formation of supersaturated salts and their crystals. ${ }^{16,17}$ In the present study we identified 9 patients ( 5 were relatives) with AMOD gene mutation and our prior hypothesis, patients with $U M O D$ gene mutation have more deterioration effects than others. These worsening effects may lead to hemodialysis impaired control of nitrogenous wastes and minerals. UMOD has been generated by the identification of UMOD mutations as basis of hereditary dominant renal diseases, now changed to uromodulin-associated kidney diseases (UAKDs), presenting with tubulointerstitial fibrosis, defective urinary concentration, hyperuricaemia, and kidney failure. The association between $U M O D$ gene risk variants and susceptibility to CKD and hypertension was found to be due the link between $U M O D$ gene and hypertension was found to be caused by over activation of the TAL sodium-potassiumchloride co-transporter NKCC2, pointing to UMOD as a therapeutic target for lowering blood pressure and maintaining renal function. ${ }^{16}$

In the current study high levels of creatinine were observed in all patients with Uromodulin gene mutation, hence about $60 \%$ of the patients with mutation were also detected with high urea. Surprisingly, Serum uric acid was found normal in most patients with $U M O D$ gene mutation, though we expected to find it high in all cases. This might be due to effect of dialysis. However, there is a lack of studies investigated the issue of the relationship between UMOD gene mutation and disturbances of nitrogenous wastes of patients under dialysis. A recent study has reported similar findings regarding our results of serum creatinine and urea, but not serum uric acid. UMOD gene mutation associated significantly with serum creatinine concentration $(\mathrm{SCr})$ in Icelandic subjects. The results validate the link between the UMOD variant and both $\mathrm{CKD}$ and $\mathrm{SCr}$ increases significantly with both age $(\mathrm{P}=3.0 \mathrm{x} 10(-17))$ and number of comorbid diseases $(\mathrm{P}=0.008)$. The findings suggest that the UMOD gene mutation may influence the adaptation of the kidney to age-related risk factors of kidney disease such as hypertension and diabetes. UMOD gene mutation also associates with serum urea $(\mathrm{P}=1.0 \times 10(-6))$, uric acid $(\mathrm{P}=0.0064) .{ }^{1718}$

Although, several studies have suggested that the level of uromodulin in the urine could represent a valuable biomarker for the development of CKD, ${ }^{19}$ but we suggest the use of the levels of nitrogenous products during dialysis as indicators of UMOD gene mutation. Such patients with constant biomarkers elevation can be further submitted to gene analysis. UMOD gene mutation causes hyperuricemia with decreased renal excretion of UMOD and uric acid, suggesting a role for UMOD in the regulation of plasma uric acid. ${ }^{20}$ Since, Uromodulin protein is the most abundant protein excreted in the normal urine that expressed by epithelial cells of the thick ascending limb (TAL) of Henle, mutations in the UMOD gene coding for uromodulin cause a dominant form of tubulointerstitial kidney disease (ADTKD), characterized by defective urinary concentrating ability, hyperuricemia, high creatinine, high urea level, and progression to ESRD. ${ }^{21}$

Regarding Minerals, only serum Sodium and Calcium were found to be significantly low among cases with $U M O D$ gene mutation in the present study. It was expected serum Sodium to be high since, $U M O D$ genes coding for proteins preventing calcium salt precipitation. Some studies suggest that tubular fluid super saturation with respect 
to calcium and phosphate predisposes to calcium-oxalate stones by triggering cellular mechanisms that lead to the Randall's plaque formation. ${ }^{22}$ With the lack of literature in this context, but was found that an increase in dietary salt and the loop diuretic, furosemide, increased expression of THP in the rat. The data support the involvement of this unique protein in the function of the uromodulin protein during changes in dietary salt. These facts suggest that restriction of dietary salt may be beneficial in cast nephropathy in multiple myeloma and recurrent nephrolithiasis, two diseases in which uromodulin can play an essential pathogenetic part. ${ }^{23}$

Nevertheless, this study has some limitations, since many confounders were not controlled, as well as the small number of cases with $U M O D$ gene mutation. Comorbid diseases such as, hypertension, and diabetes, as well as other factors including age, creatinine excretion, diabetes, and urinary volume are independent clinical correlates of urinary uromodulin excretion. ${ }^{24}$ Moreover, there are important cofounders associated with levels of serum creatinine and urea, and especially so with patients on hemodialysis. Cofounders such as: muscle mass, body weight, dialysis frequency and modality and $\mathrm{Kt} / \mathrm{V}$, preserved renal function and dieresis. ${ }^{25}$ Since the data of the present study was collected from the patients' files, several confounders were regarded as limitations. However, patients on haemodialysis have removal of nitrogenous waste products by hemodialysis. If a patient is anuric, and some hemodialysis patients are, so there is no tubular function at all. If catheter of arteriovenous fistula (AVF) is not working properly, or $\mathrm{Kt} / \mathrm{V}$ is low, clearance of waste products is poorer so we think there are many cofounders, which should be taken into account when dialysis population is studied.

\section{Conclusion}

Patients with renal failure have more potentiality for deteriorated Minerals and nitrogenous wastes than others. The associations of uromodulin excretion with biomarkers of tubular functions and kidney extents propose that it may reflect tubule activity of uromodulin even in renal failure, which necessitate the need for further research in this context.

\section{Compliance with ethical standards}

\section{Funding}

The study was supported by College of Medicine, University of Hail, and KSA.

\section{Informed consent}

Informed consent was obtained from all individual participants included in the study.

\section{Ethical consent}

All procedures performed in this study were in accordance with the ethical standards of the institutional research committee and with the 1964 Helsinki declaration and its later amendments or comparable ethical standards.

\section{Acknowledgement}

None.

\section{Conflicts of interest}

The author declares there is no conflict of interest.

\section{References}

1. National Kidney Foundation. K/DOQI clinical practice guidelines for chronic kidney disease: evaluation, classification, and stratification. $\mathrm{Am}$ J Kidney Dis. 2002;39(2 Suppl 1):S1-S266.

2. KDIGO: Kidney Disease Improving Global Outcomes.) KDIGO Clinical Practice Guideline for the Diagnosis, Evaluation, Prevention, and Treatment of Chronic Kidney Disease-Mineral and Bone Disorder (CKDMBD). Kidney Int. 2009;76(Suppl 113).

3. KDIGO (Kidney Disease Improving Global Outcomes. KDIGO 2012 Clinical Practice Guideline for the Evaluation and Management of Chronic Kidney Disease. Kidney Int Suppl. 2013;3(1):1-150.

4. Ahmed HG, Ginawi IA, Al-hazimi AM. Prevalence Estimates of Chronic Kidney Disease in Hail Region, KSA: in a Comprehensive Survey. International Journal of Science and Research. 2014;3(7):252-256.

5. Al-Sayyari AA, Shaheen FA. End stage chronic kidney disease in Saudi Arabia. A rapidly changing scene. Saudi Med J. 2011;32(4):339-346.

6. Ahmed HG, Ginawi IA, Alshammari FD, et al. Current Burden of diabetes in Kingdom of Saudi Arabia in an epidemiological survey. Egypt Acad J Biolog Sci. 2014;6(2):85-91.

7. Ahmed HG, Ginawi IA, Al- hazimi AM. Prevalence of Hypertension in Hail Region, KSA: in a Comprehensive Survey. International Journal of Sciences: Basic and Applied Research. 2014;17(2):288-296.

8. Ahmed HG, Ginawi IA, Elasbali AM, et al. Prevalence of Obesity in Hail Region, KSA: in a comprehensive Survey. $J$ Obes. 2014; doi: $10.1155 / 2014 / 961861$.

9. Raffler G, Zitt E, Sprenger-Mähr $\mathrm{H}$, et al. Autosomal dominant tubulointerstitial kidney disease caused by uromodulin mutations: seek and you will find. Wien Klin Wochenschr. 2016;128(7-8):291-294.

10. Turner JJ, Stacey JM, Harding B, et al. UROMODULIN mutations cause familial juvenile hyperuricemic nephropathy. J Clin Endocrinol Metab. 2003;88(3):1398-1401.

11. Anthony J Bleyer, P Suzanne Hart. Autosomal Dominant Tubulointerstitial Kidney Disease, UMOD-Related. (ADTKD-UMOD). Initial Posting: January 12, 2007; Last Update: September 12, 2013.

12. Wolf MT, Mucha BE, Attanasio M, et al. Mutations of the Uromodulin gene in MCKD type 2 patients cluster in exon 4 , which encodes three EGF-like domains. Kidney Int. 2003;64(5):1580-1587.

13. Wolf MT, Saunier S, O'Toole JF, et al. Mutational analysis of the RPGRIP1L gene in patients with Joubert syndrome and nephronophthisis. Kidney Int. 2007;72(12):1520-1526.

14. Otto EA, Helou J, Allen SJ, et al. Mutation analysis in nephronophthisis using a combined approach of homozygosity mapping, CELI endonuclease cleavage, and direct sequencing. Hum Mutat. 2008;29(3):418-226.

15. Ginawi, Ahmed HG, Ashankyty IM, et al. A survey for potential risk factors for susceptibility to Chronic Kidney Disease in Hail Region, KSA. Management in Health. 2013;17(12):31-36.

16. Scolari F, Izzi C, Ghiggeri GM. Uromodulin: from monogenic to multifactorial diseases. Nephrol Dial Transplant. 2015;30(8):1250-1256.

17. Onoe T, Yamada K, Mizushima I, et al. Hints to the diagnosis of uromodulin kidney disease. Clin Kidney J. 2016;9(1):69-75.

18. Gudbjartsson DF, Holm H, Indridason OS, et al. Association of variants at UMOD with chronic kidney disease and kidney stones-role of age and comorbid diseases. PLoS Genet. 2010;6(7):e1001039.

19. Fugiel A, Kuzniewski M, Fedak D. Uromodulin can it be a new marker of kidney damage?]. PrzeglLek. 2013;70(11):976-982. 
20. Han J, Liu Y, Rao F, et al. Common genetic variants of the human uromodulin gene regulate transcription and predict plasma uric acid levels. Kidney Int. 2013;83(4):733-740.

21. Troyanov S, Delmas-Frenette C, Bolle'e G, et al. Clinical, Genetic, and Urinary Factors Associated with Uromodulin Excretion. Clin J Am Soc Nephrol. 2015;11:1-8.

22. Arcidiacono T, Mingione A, Macrina L, et al. Idiopathic calcium nephrolithiasis: a review of pathogenic mechanisms in the light of genetic studies. Am J Nephrol. 2014;40(6):499-506.
23. Ying WZ, Sanders PW. Dietary salt regulates expression of TammHorsfall glycoprotein in rats. Kidney Int. 1998;54(4):1150-1156.

24. Pruijm M, Ponte B, Ackermann D, et al. Associations of Urinary Uromodulin with Clinical Characteristics and Markers of Tubular Function in the General Population. Clin J Am Soc Nephrol. 2016;11(1):70-80.

25. Wong J, Sridharan S, Berdeprado J, et al. Predicting residual kidney function in hemodialysis patients using serum $\beta$-trace protein and $\beta 2$ microglobulin. Kidney International. 2016;89(5):1090-1098. 